\title{
Molecular evidence of intraspecific variability in Lysidice ninetta (Polychaeta: Eunicidae) in the Mediterranean Sea
}

\author{
Maria Alessandra Iannotta, Maria Cristina Gambi, Francesco Paolo Patti*
}

Laboratory of Functional and Evolutionary Ecology, Stazione Zoologica Anton Dohrn, 8077 Ischia, Napoli, Italy

\begin{abstract}
A first study of the phylogeography of the polychaete Lysidice ninetta Audouin \& MilneEdwards (Polychaeta: Eunicidae) in the Mediterranean Sea, based on analyses of the molecular markers ITS1 and COI, indicated the occurrence of strong intraspecific variability and possible sibling species. Here, we report further evidence of the presence of sibling species within L. ninetta, revealed by analysing a new molecular marker (16S rRNA) and supported by preliminary morphological observations. Specimens were collected in association with the seagrass Posidonia oceanica in 6 meadows of the Mediterranean basin; in one of the meadows in which putative siblings co-occurred (Cava meadow off the island of Ischia, Naples, Italy), additional samples were collected for genetic and morphological analysis. The mitochondrial region $16 \mathrm{~S}$ rRNA of 78 specimens revealed 2 haplotypes (nA and $n \mathrm{~B}$ ); morphological characters, associated with these 2 molecular clades were also observed in a sub-set of the analysed specimens of $L$. ninetta, revealing the presence of 2 morphotypes. The morphotype termed 'dark', characterised by a typical dark colour pattern on the prostomium and first anterior segments, as well as by black aciculae all along the examined body portion, matching quite well with the description of $L$. ninetta from the Atlantic type locality, corresponded to haplotype $n A$. The morphotype termed 'light', with lighter colouration of the prostomium and first anterior segments, and both black and yellow aciculae on the examined body portion, corresponded to haplotype $n \mathrm{~B}$, suggesting the existence of a different species. The hypotheses that can be addressed are the following: (1) only a single new species (the light morph/genotype) is present, while the dark morph corresponds to the original L. ninetta species; (2) both morphs/genotypes (dark and light) are new taxa and need to be fully and properly described; and (3) one or both of the species corresponds to previously described species, synonymised by previous authors as L. ninetta. In all cases there is an urgent need for revision of the genus Lysidice and the nominal species in the Mediterranean Sea basin. This is a complex task far beyond the scope of this work.
\end{abstract}

KEY WORDS: Polychaetes $\cdot$ Eunicidae $\cdot 16 \mathrm{~S}$ rRNA $\cdot$ Mitochondrial DNA $\cdot$ Mediterranean Sea

\section{INTRODUCTION}

An increasing number of invertebrate species, previously considered common and/or geographically widespread, have been identified as 'siblings' or species complexes (Knowlton 1993, Palumbi 1994). Among polychaetes, which represent one of the most speciose invertebrate groups and which are widespread in various benthic habitats, the number of cryptic species, since the first 'classic' case of the Capitella capitata species complex (Grassle \& Grassle 1976), has increased, including examples of quite specialized taxa, such as the meiofaunal species (Westheide \& Schmidt 2003). In more recent years, molecular approaches, coupled with cladistic analysis, have also shed light on the phylogenetic relationships among closely related taxa.

Often, morphologically very similar species from relatively distant locations show genetic divergence (Schröder \& Walsh 2007), while it is less common to determine genetic differentiation in taxa sharing a common habitat and similar ecological requirements (Maltagliati et al. 2004, Barluenga et al. 2006). Besides, 
although few geographical obstacles are faced by pelagic larvae in the marine realm (Palumbi 1992, Pechenik 1999), many molecular studies of marine organisms show that genetic divergence may occur at small spatial scales or with minimal morphological diversifications (Palumbi 1992, Knowlton 1993, 2000, Tarjuelo et al. 2004, Collin 2005, Bleidorn et al. 2006). On the other hand, differences among sibling species have often been coupled with differences in lifehistory traits (e.g. reproductive features, larval development) (Kruse et al. 2003).

Lysidice ninetta Audouin \& Milne Edwards, 1833 (Polychaeta: Eunicidae) is a polychaete associated with various vegetated habitats in the Mediterranean Sea (Martin 1987), including Posidonia oceanica meadows, where the species bores into sheaths (the remains of former leaf bases persisting along the rhizome) (Gambi 2000). Eunicida represents one of the higher, morphologically most well-described clades of polychaetes (Struck et al. 2006, Zanol et al. 2007a), but, being an order containing 7 recognised families (Eunicidae is one of them) and >900 nominal species in 100 genera (Rouse \& Pleijel 2006) some uncertainties still persist. Focusing on the taxonomy, phylogeny and ecology of species in the genus Lysidice, data on molecular phylogeny have only recently indicated that this genus is paraphyletic with respect to Marphysa and Nicidion, while Nematonereis is nested within the Lysidice (Zanol et al. 2007b). In addition, despite the high diversity of species within the Eunicidae, few data on the reproductive habits of this clade are available, mainly for several species belonging to the genera Palola, Eunice and Marphysa (Wilson 1991, Giangrande 1997) and, only recently, the Lysidice (Gambi \& Cigliano 2006). In the Mediterranean Sea, L. ninetta - a warmtemperate and temperate water polychaete (George \& Hartmann-Schröder 1985, Cantone 1993) - and its cogener L. collaris - a tropical species and a putative migrant from the Red Sea via the Suez canal (BenEliahu 1972) - are clearly distinguished by both morphological (Martin 1987) and molecular data (Iannotta et al. 2007). The larvae of $L$. ninetta can be designated as Type 1, i.e. warm water, short distance, neritic epipelagic, suggesting a pelagic larval stage with limited dispersal power for the species (Murina 1992, 1997). Considering the reproductive biology of $L$. ninetta in populations inhabiting Posidonia meadows, the species shows features that indicate reproduction by schizogamy (Gambi \& Cigliano 2006) and that are consistent with a possible planktotrophic development of the larvae. Previous genetic results based on both mitochondrial (COI) and nuclear (ITS1) data show that $L$. ninetta is clearly separated from its cogener $L$. collaris and also show high intraspecific differentiation, particularly at some sampling sites, suggesting the presence of sibling species (Iannotta et al. 2007). In the present work, a third molecular marker (16S rRNA) has been used to analyse 6 populations from the Mediterranean basin. At one of the studied locations where such putative siblings co-occurred, the $P$. oceanica meadow off Ischia (Cava dell'Isola, Naples, Italy), additional samples were collected in order to perform preliminary morphological observations. The aim of the present study was to demonstrate the occurrence of sibling species within L. ninetta and to relate the genetic patterns with distinct morphological features that would allow discrimination of potentially different species. In the Mediterranean Sea, various species of Lysidice have been described (e.g. L. margaritacea Claparède, 1868), but all of them lack proper formal description and suitable illustration, and were thus synonymised with $L$. ninetta by Fauvel (1923). In addition, no type material for any of these nominal species is available, while the re-description of the type species for the genus Lysidice ( $L$. ninetta) sampled near the type locality is still in progress (Carrera-Parra et al. 2007 and their unpubl. data). Therefore, the analysis of the 2 morphotypes described in the present study and their taxonomic status, with respect to the previous nominal species, is preliminary and limited; a conclusive analysis would require additional material and a full revision of the genus for the entire Mediterranean. This represents a complex task that is far beyond the intended scope of this work.

\section{MATERIALS AND METHODS}

Population sampling and morphological observations. Between 2000 and 2007 a total of 78 individuals of Lysidice ninetta were sampled from 6 populations of Posidonia oceanica meadows, distributed among the western, central and eastern parts of the Mediterranean basin (Fig. 1, Table 1). Collection was conducted by SCUBA diving and consisted of sampling living orthotropous (vertically oriented) shoots of the seagrass $P$. oceanica in a depth range of 11 to $28 \mathrm{~m}$ and by extracting the worms from the leaf sheaths along the rhizomes (Gambi 2000). At one of these study sites, located off Ischia (Cava dell'Isola, Tyrrhenian Sea, Naples, Italy) (Fig. 1, Table 1), the 2 possible sibling species cooccurred (Iannotta et al. 2007). Therefore, we selected this site for additional sampling and also to obtain specimens for the preliminary morphological analyses. Among the 57 individuals collected from this locality, 25 specimens were cut into 2 parts: (1) an anterior section, including the prostomium and at least the first 30 to 40 segments, was used for morphological observations and fixed in $4 \%$ formalin and (2) a posterior section preserved in absolute alcohol was used for the molecular 


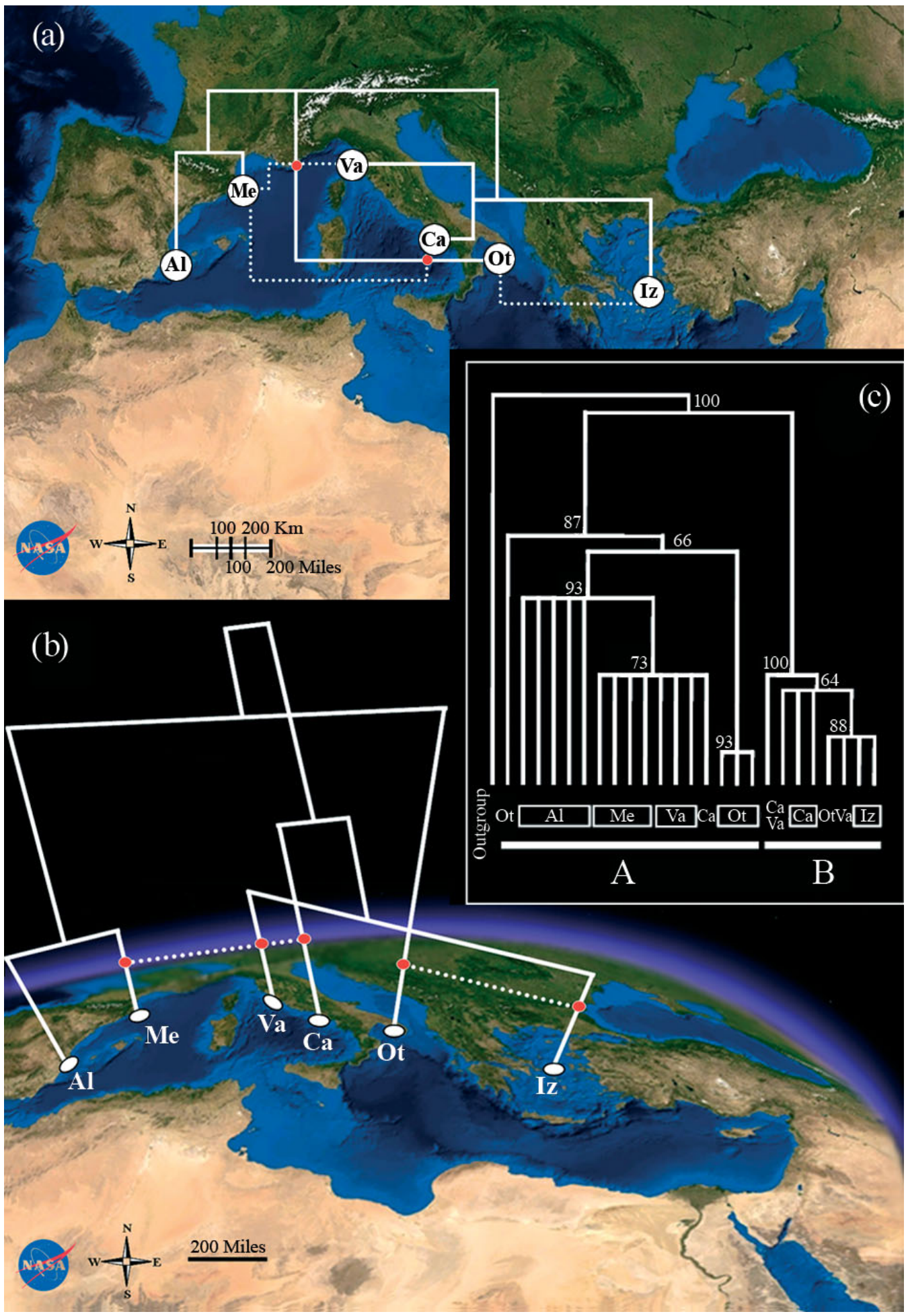

Fig. 1. Lysidice ninetta sampling sites in the Mediterranean Sea (Al: Alicante; Me: Medes; Va: Vada; Ca: Ischia [Cava dell'Isola]; Ot: Otranto; Iz: Izmir) and phylogenetic reconstructions. (a) Maximum-likelihood (ML) network visualised over a cartographic background. Dotted lines and red circles show the connections among populations based on the individuals' distributions. (b) ML tree with associated geographical coordinates displayed with the Mesquite Cartographer. Tree branch lengths are distorted to fit the geography. Dotted lines and red circles (median vectors) represent the alternative hypothesis for connection among populations. (c) ML tree constructed with the sequences of the 6 populations from the Mediterranean Sea. The 2 major clades (A and B) and the secondary groups are displayed. The minor clades correspond to those from the ML network (Panel a) and ML tree after Mesquite Cartographer 
Table 1. Lysidice ninetta. Location and no. of samples taken at the 6 sampling sites for the morphological and molecular analyses, and GenBank accession numbers of the subsequent DNA sequences. Total no. of individuals = 78; at Ischia (Cava dell'Isola), 25 of the 57 individuals collected were cut into anterior and posterior parts for morphological and molecular analyses, respectively. Location codes in parentheses refer to those given in Fig. 1

\begin{tabular}{|c|c|c|c|c|}
\hline Site & Location & $\begin{array}{l}\text { Morphol. } \\
\text { analysis (n) }\end{array}$ & $\begin{array}{l}\text { Mol. } \\
\text { analysis (n) }\end{array}$ & GenBank accession number \\
\hline \multicolumn{5}{|l|}{ Spain } \\
\hline Alicante (Al) & $38^{\circ} 45^{\prime} \mathrm{N}, 00^{\circ} 0.7^{\prime} \mathrm{E}$ & & 5 & FJ986226-FJ986230 \\
\hline Medes Islands (Me) & $42^{\circ} 02^{\prime} \mathrm{N}, 03^{\circ} 13^{\prime} \mathrm{E}$ & & 4 & FJ986231-FJ986234 \\
\hline \multicolumn{5}{|l|}{ Italy } \\
\hline Vada (Va) & $43^{\circ} 21^{\prime} \mathrm{N}, 10^{\circ} 26^{\prime} \mathrm{E}$ & & 5 & $\begin{array}{l}\text { FJ986235-FJ986237, FJ986243 } \\
\text { FJ986245 }\end{array}$ \\
\hline Ischia (Cava dell'Isola) (Ca) & $40^{\circ} 44^{\prime} \mathrm{N}, 13^{\circ} 51^{\prime} \mathrm{E}$ & $5+25$ & $27+25$ & $\begin{array}{l}\text { FJ986238, FJ986246-FJ986248, } \\
\text { FJ986251-FJ986298 }\end{array}$ \\
\hline Otranto (Ot) & $40^{\circ} 14^{\prime} \mathrm{N}, 18^{\circ} 27^{\prime} \mathrm{E}$ & & 5 & FJ986239-FJ986242, FJ986244 \\
\hline \multicolumn{5}{|l|}{ Turkey } \\
\hline Izmir (Iz) & $37^{\circ} 43^{\prime} \mathrm{N}, 27^{\circ} 10^{\prime} \mathrm{E}$ & & 2 & FJ986249, FJ986250 \\
\hline Total samples & & 30 & 73 & \\
\hline
\end{tabular}

analyses. Among the remaining 32 smallest individuals, 5 were preserved in their entirety in $4 \%$ formalin for morphology and 27 individuals were used for further genetic analyses (Table 1). Overall, morphological observations were conducted on 30 individuals of the ' $L$. ninetta complex' (5 whole specimens and 25 anterior segments; Table 1) among those collected in the Cava meadow. Analysis was conducted on a stereomicroscope and an optical microscope. Individuals collected at Cava meadow for the genetic analyses were differentiated into 2 morphotypes, based mainly on body and aciculae colouration and labelled as 'dark' and 'light' morphs. Photographs were taken of the most representative specimens with a Canon digital camera mounted on top of a stereomicroscope. Comparisons were made with the current description of $L$. ninetta according to the available literature (Fauvel 1923, Martin 1987).

DNA extraction, amplification and sequencing. DNA analyses were conducted on 73 individuals of the 'Lysidice ninetta complex', of the total 78 individuals collected (Table 1). The DNA was extracted by homogenizing the animal with a mortar, using $500 \mu \mathrm{l} 2 \times$ CTAB extraction buffer (50 mM Tris $\mathrm{HCl}$ [pH 8.0], $0.7 \mathrm{M}$ $\mathrm{NaCl}, 10 \mathrm{mM}$ EDTA, 1\% CTAB, 0.4\%-mercaptoethanol) and by adding Proteinase $\mathrm{K}$ to a final concentration of $0.1 \mathrm{mg} \mathrm{ml}^{-1}$. The standard protocol of Doyle \& Doyle (1987) was followed with 1 extra wash in phenol: chloroform:isoamylalcohol (25:24:1) and 1 in chloroform:isoamylalcohol (24:1) in order to eliminate polysaccharides. The polymerase chain reaction (PCR) was standardized to amplify $481 \mathrm{bp}$ of the $16 \mathrm{~S}$ rRNA region, with the universal primers $16 \mathrm{SAR}$ (5'-CGC CTG TTT ATC AAA AACAT-3') and 16SBR (5'-CCGGTC TGA ACT CAG ATC ACG T-3') (Palumbi 1996). A specific internal primer, 90F, was constructed (5'-CTG ACCGTGCTAAGG TAGCG-3') and used with the universal primer $16 \mathrm{SBR}$ to optimize the results. A mixture of $20 \mu \mathrm{l}$ final volume containing 20 to $50 \mathrm{ng}$ template DNA, $2 \mu$ l of $10 \times$ Roche diagnostic PCR reaction buffer, $2 \mu \mathrm{l}$ dNTPs $10 \times(2 \mathrm{mM}), 1 \mu \mathrm{l}$ of each primer

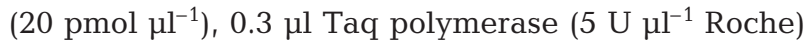
and $0.2 \mu \mathrm{l}$ BSA was used to amplify the DNA target. PCR was performed in a Hybaid thermal cycler, following a hot-start method: a 5 min denaturing step at $94^{\circ} \mathrm{C}$, 40 cycles of denaturing for $30 \mathrm{~s}$ at $94^{\circ} \mathrm{C}$, primer annealing for $30 \mathrm{~s}$ at 53 to $55^{\circ} \mathrm{C}$ and elongation for $1 \mathrm{~min}$ at $72^{\circ} \mathrm{C}$, with a final 7 min elongation step at $72^{\circ} \mathrm{C}$. Purified PCR products were produced using a QIAquick gel extraction kit (Qiagen) and then sequenced on a Beckman Ceq 2000 automatic sequencer, using a dye-terminator cycle sequencing kit (Beckman) according to the manufacturer's instructions. Sequences were assembled using the DNASTAR computer package (Lasergene), supplied with the Beckman sequence. The program Codon Code Aligner (CodonCode Corporation) was used to align all sequences (forward and reverse strands were analysed for each sample). All sequences have been submitted to GenBank (Accession Numbers FJ986226 to FJ986298; Table 1).

Phylogenetic analyses. The neighbour-joining, parsimony and maximum-likelihood evolutionary trees were computed with all individuals sampled. For the analyses, Lysidice collaris was used as the outgroup. A sequence of $L$. ninetta from the GenBank (Accession Number AY838834) was also used for further comparison with our sequence data. A neighbour-joining (NJ) tree was obtained with Mega Ver. 3.1 (Kumar et al. 2004), and a consensus tree was calculated from 1000 bootstrap replicates. Parsimony analyses were conducted with the program Paup*4.0 (Swofford 2003) using the heuristic search option and the following assumptions: input order for the sequences and 
absence of weights for the sites, the analysis of 1000 bootstrap replicates, and use of ordinary parsimony. Modeltest 3.06 (Posada \& Crandall 1998), with the Akaike information criterion, was used to determine the models of sequence evolution that best fit the 'Lysidice ninetta complex' individuals sampled in both the 6 populations of the Mediterranean Sea and exclusively at the Ischia site (Cava dell'Isola meadow). The models chosen were, respectively, GTR + I and HKY85 + G. Maximum-likelihood (ML) analyses were calculated with Paup*4.0 (Swofford 2003). Tree-bisection reconnection (TBR) branch swapping and 1000 bootstrap replicates were performed to infer the best phylogenetic tree. The WinModel test was used as a Windows PC Modeltest front-end (WinmodeltestXP, Windows 32-bit front-end, distributed by the co-author and available at: fpatti@szn.it). The combined approach of the ML tree topology and Cartographer, a Mesquite package for plotting geographic data (Maddison \& Maddison 2008), was used to compare the 6 populations (Kidd \& Ritchie 2006).

Population genetic analyses. Analysis of molecular variance (AMOVA) was performed with the Arlequin program (Excoffier et al. 1992) in order to investigate the hierarchical population structure among and within the 6 populations (Table 2). In the first hypothesis, all populations were harboured in a unique group; in the second, 3 geographical groups were formed (western, central and eastern Mediterranean Sea). In the last hypothesis, the 2 phylogenetic clades obtained via ML analysis were considered the 2 groups for the AMOVA test. Significance of values was tested performing 16000 random permutations of the data matrix to represent $<1 \%$ of differences, with the exact probability in $99 \%$ of cases (Guo \& Thompson 1992). An exact test for all population differentiations was computed to test the random distribution of haplotypes among localities. $F_{\text {ST }}$ was calculated using a permutational approach, and its significance was tested by distributing individuals randomly into populations 10000 times. Tajima's (1989) $D$ and Fu's (1997) $F_{\mathrm{s}}$ tests were conducted, as they are statistically powerful enough to establish whether a population is far from the equilibrium size. Moreover, a mismatched distribution analysis is useful in understanding whether the populations have been affected by expansion or bottleneck occurrences. In the mismatched distribution analysis, both time and population size are measured in mutational units. The conventional unit of time is $\tau=2 \mu-t$, where $t$ is time in generations and $\mu$ is the mutation rate per DNA fragment. Population size is measured by $\theta=$ $2 \mathrm{~N} \mu$, where $\mathrm{N}$ is the effective population size. $\theta_{0}$ and $\theta_{1}$ are parameters of demographic expansion, assuming a model of sudden expansion under which the population size increased from $\mathrm{N}_{0}$ to $\mathrm{N}_{1} t$ generations ago. The population size at time 0 is $\theta_{0}=2 \mathrm{~N}_{0} \mu_{\text {; }}$ the population size at time 1 is $\theta_{1}=2 \mathrm{~N}_{1} \mu$. All tests were computed using Arlequin.

\section{RESULTS}

\section{Morphological observations}

Preliminary morphological observations of the collected specimens of the 'Lysidice ninetta complex' in the Ischia population identified 2 morphotypes, which we designated 'dark' and 'light' (Fig. 2a,b). This separation for genetic and other analyses was based on preliminary discrimination of the specimens according to

Table 2. Lysidice ninetta. AMOVA among and within the 6 populations from the Mediterranean Sea. $F_{\mathrm{ST}}$ : total fixation index without groups among populations, $F_{\mathrm{CT}}$ : value among geographical groups, $F_{\mathrm{SC}}$ : value among populations within groups

\begin{tabular}{|c|c|c|c|c|c|c|}
\hline Source of variation & $\mathrm{df}$ & SS & Variance components & Variation (\%) & Fixation indices & $\mathrm{p}$ \\
\hline \multicolumn{7}{|l|}{ Without groups } \\
\hline Among populations & 5 & 252.5 & 9.4 & 44.1 & $F_{\mathrm{ST}}: 0.4$ & 0.0015 \\
\hline Within populations & 19 & 225.9 & 11.9 & 55.9 & & \\
\hline Total & 24 & 478.4 & 21.3 & 100 & & \\
\hline \multicolumn{7}{|l|}{ Three groups } \\
\hline $\begin{array}{l}\text { Among } 3 \text { geographical groups: western, } \\
\text { central, eastern Mediterranean Sea }\end{array}$ & 2 & 163.7 & 6.0 & 26.9 & $F_{\mathrm{CT}}: 0.3$ & 0.13 \\
\hline Among populations within groups & 3 & 88.8 & 4.5 & 20.2 & $F_{\mathrm{SC}}: 0.3$ & $<0.001$ \\
\hline Within populations & 19 & 225.9 & 11.9 & 52.9 & $F_{\mathrm{ST}}: 0.5$ & $<0.01$ \\
\hline Total & 24 & 478.4 & 22.5 & 100 & & \\
\hline \multicolumn{7}{|l|}{ Two groups } \\
\hline $\begin{array}{l}\text { Among } 2 \text { groups identified with the } \\
\text { phylogenetic analysis (Clades A \& B) }\end{array}$ & 1 & 340.5 & 29.9 & 82.1 & $F_{\mathrm{CT}}: 0.8$ & $<0.01$ \\
\hline Among populations within groups & 7 & 100.6 & 4.6 & 12.7 & $F_{\mathrm{SC}}: 0.7$ & $<0.001$ \\
\hline Within populations & 16 & 30.3 & 1.9 & 5.2 & $F_{\mathrm{ST}}: 0.9$ & $<0.0001$ \\
\hline Total & 24 & 471.4 & 36.4 & 100 & & \\
\hline
\end{tabular}




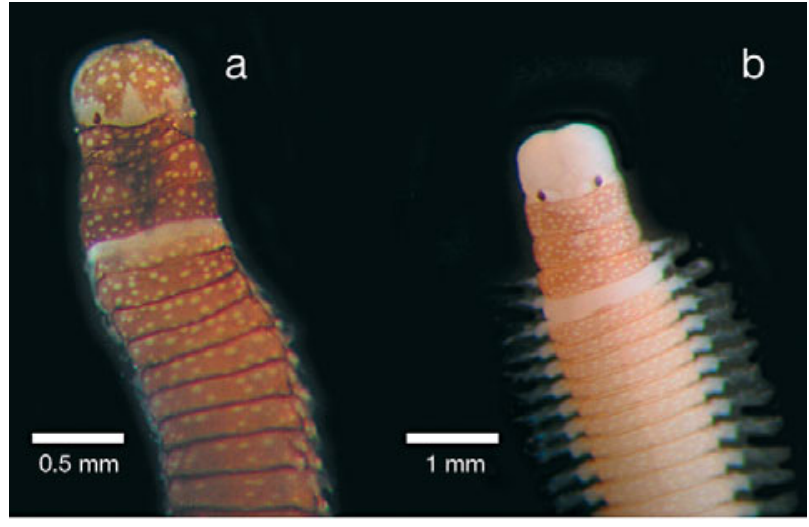

Fig. 2. Lysidice ninetta (a) 'dark' morph and (b) 'light' morph

their anterior body colouration. After this first distinction, further morphological characters were analysed. The dark morph (Fig. 2a) was characterised by a rounded prostomium, with three short occipital antennae of which the middle antenna was slightly longer and thicker than the 2 lateral ones. However, the antennae never go over the prostomium when stretched. The eyes were rounded. The prostomium and first anterior segments were characterised by a very dark brown-reddish colouration with fine white spots. The white collars on the second and third segments were very evident and contrasted with the brownish colouration of the rest. The general appearance of the anterior part was very close to the illustration provided by Martin (1987). The dark morphs were also characterised by the presence of dark aciculae all along the body (on the few whole specimens available), which started from the first segments (third or fourth chaetiger).

The light morph (Fig. 2b) showed a rounded prostomium and upper lips, although in some specimens fixation may have led to a slightly bilobed impression. The occipital antennae were short, pointed and did not extend beyond the prostomium. The eyes were round in shape. The prostomium and first segments showed much lighter colouration and finer white spots, and the white collar on segments 2 and 3 was less evident, although sometimes still recognizable. The aciculae could be dark or yellow, or alternated along the body with a wide variability in colour patterns; however, it should be stressed that most of the light specimens lacked the posterior part, which thus was not observed. In both morphs, the sub-acicular hooded chaetae were yellow and the other characters (antennae, cirri, parapodial lobes) were similar. It is worth stressing that the above features, in particular colour patterns, are much better defined in small individuals $(<1 \mathrm{~cm}$ in length and $0.5 \mathrm{~mm}$ width of the third chaetiger), which are probably juveniles that are not yet reproductive
(Gambi \& Cigliano 2006). In individuals of larger size, the colour patterns tend to be less evident or to disappear. For this reason it has been difficult to use the large amount of material available from previous sampling and studies for comparison (Gambi 2000, Gambi et al. 2005).

\section{Phylogenetic analyses}

The molecular analyses computed on all individuals sampled showed similar tree topology with NJ, parsimony and ML methods. Only the ML trees are reported (Figs. 1 \& 3). The ML tree constructed with Cartographer on the sequences of the 6 populations from the Mediterranean Sea displayed 2 major clades and several secondary groups, all highly supported (Fig. 1). In the first main clade (A) (Fig. 1C), all individuals of the 2 populations from the western Mediterranean Sea (Alicante and Medes) and partial populations from the central part of the Mediterranean basin (Vada and Ischia) were included. Two other small groups identified 4 individuals from the Otranto population (eastern Mediterranean Sea). The second main clade (B) resulted in the separation of 3 small groups characterising the central-eastern part of the Mediterranean Sea. Focusing on the population from Ischia, 2 main clades, corresponding to the 2 main haplotypes, were identified ( $n \mathrm{~A}$ and $n \mathrm{~B}$; Fig. 3 ) and fit well with the 2 morphotypes designated 'dark' and 'light'. The 2 haplotypes were differentiated by 72 variable sites $(13 \%)$ and were supported by a $100 \%$ bootstrap value (Fig. 3). The haplotype $n A$ was less frequent, with identical sequences including all 'dark' individuals plus 2 'light' specimens (white dots in $n A_{i}$ Fig. 3 ), and was geneti-

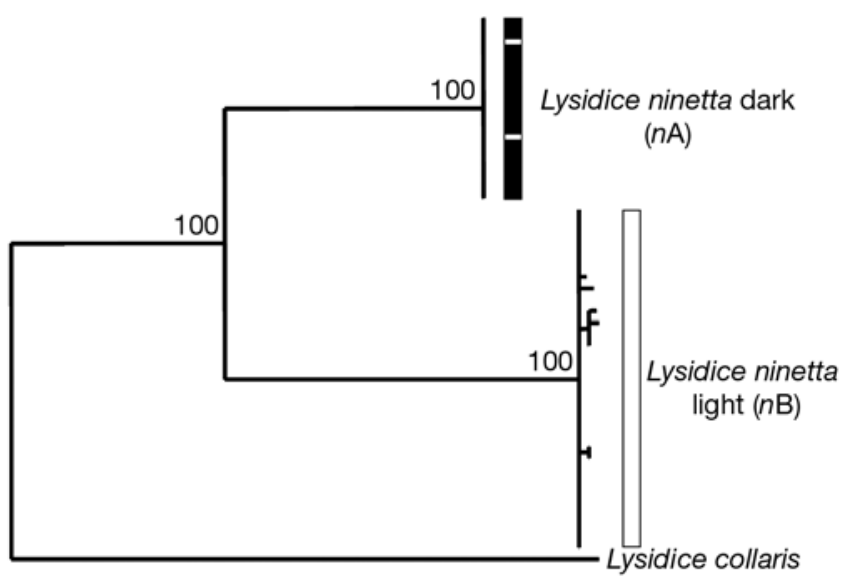

-0.005 substitutions/site

Fig. 3. Lysidice ninetta. Maximum-likelihood tree HKY85 + G model, with 1000 bootstrap replicates on the populations from Ischia (Cava dell'Isola, Tyrrhenian Sea, Naples, Italy) 
cally close to the individuals characterising Clade A (Fig. 1). The more common haplotype $n B$ (light morph) showed a strong genetic similarity with sequences in Clade B (Fig. 1). The latter haplotype appears more diversified than the first one, also including 2 minor clusters supported by bootstrap values $<65 \%$.

\section{Population genetic analyses}

The 'Lysidice ninetta complex' specimens from the Mediterranean populations analysed were clearly separated into 2 different genetic clades (Fig. 1), and the AMOVA analyses corroborated these results. Different hypotheses can be formulated to explain the observed pattern. To test one such hypothesis, all individuals were considered randomly dispersed among the 6 populations of the Mediterranean basin. The differences within populations explained higher variability $(55.9 \%)$ with respect to the variance among populations $(44.1 \%)$, which, however, showed a strongly significant $F_{\mathrm{ST}}$ value $(\mathrm{p}<0.0001)$. These data have led to the rejection of this null hypothesis. Focusing on the other 2 hypotheses, populations were divided both in relation to their geographical position and by considering them as groups of the 2 clades obtained from phylogenetic analyses (Fig. 1). In the first case, variability among the groups was not supported ( $p=0.14$ ), whereas, in the second case, the highest percentage of variation was found among the phylogenetic groups $(82.0 \%)$, which was supported by a significant $p$-value (<0.01). Applying Tajima's (1989) D and Fu's (1997) $F_{\mathrm{s}}$ tests to the phylogenetic Groups A and B (Fig. 1), the results showed no significant values (Table 3 ), leading to the hypothesis that individuals were susceptible to balancing selection and high variability (Sirna Terranova et al. 2006). Mismatched distribution analysis, displaying the multimodal shapes expected for populations at equilibrium (Harpending 1994) (Fig. 4a,b), supported the results of the statistical tests.

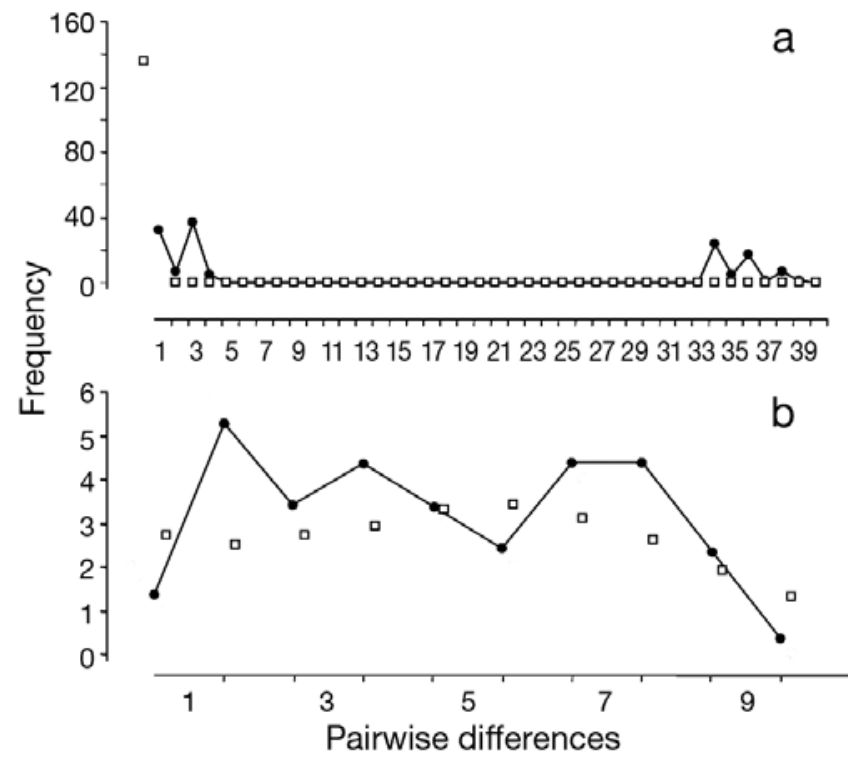

Fig. 4. Lysidice ninetta. Mismatch distribution based on 25 sequences of a $481 \mathrm{bp}$ fragment of the mitochondrial gene 16S rRNA. The line shows the frequency distribution of the observed pairwise differences. White squares show the frequency distribution of the expected pairwise differences under the sudden expansion model. (a) L. ninetta 'dark' populations from the Mediterranean Sea and (b) L. ninetta 'light' populations from the Mediterranean Sea

\section{DISCUSSION}

A phylogenetic study of the 6 populations of the putative 'Lysidice ninetta complex' examined here has provided evidence of the presence of 2 main genetic groups with distinct distributions in the Mediterranean Sea. Several hypotheses have been formulated on the number of biogeographic regions and their boundaries in the Mediterranean basin (Bianchi 2007). Considering the theory of a boundary in the mid-Ionian Sea (Curini-Galletti \& Casu 2003), in which Sicily, Calabria and the Gulf of Taranto would be included in the western Mediterranean basin, it is difficult to explain the distribution of specimens in the Otranto population. In fact, all except one individual of the Otranto population are separated from the samples from Turkey and are included in the clade characterising the westerncentral part of the Mediterranean Sea (Alicante, Medes and Vada stations) (Fig. 1a). Previous data on the phylogeographic distribution of L. ninetta, obtained using both nuclear and mitochondrial markers (ITS1 and COI), have already provided evidence of the presence of 2 main clades for this species, 
but the Otranto individuals were genetically dispersed between the 2 groups using the nuclear marker, whereas, using the mitochondrial marker, they were all harboured in the clade characterising the populations of the eastern Mediterranean basin (Iannotta et al. 2007). The genetically contrasting results and the few data available on the larval development of $L$. ninetta (pelagic larval stage, but with limited dispersal) could lead to the hypothesis that the presence of hybrids in the Otranto population is due to the species living in a geographical mixing zone where it is common to find processes of hybridization (Arnold 1997). Even if the individuals analysed are few, an alternative hypothesis may be the incomplete lineage sorting of the target mitochondrial region (16S rRNA). The retention of ancestral polymorphisms, leading to misinterpretation of the relationships among populations (Maddison \& Knowles 2006), would be an interesting topic for future investigations.

The 2 morphotypes observed at the Ischia site (Cava dell'Isola) correspond to the 2 haplotypes identified in the same population when supplementary material was analysed ( $n \mathrm{~A}$ and $n \mathrm{~B}_{;}$Fig. 3). Comparing the sequences of the 2 main clades (A \& B; Fig. 1c) with those of the 2 Ischia haplotypes, a strong genetic similarity is found between Clades $\mathrm{A}$ and $n \mathrm{~A}$ and between Clades $\mathrm{B}$ and $n B$. Starting from this data, we hypothesise that the same correspondence could also exist from a morphological point of view and identify as the dark morph and light morph individuals belonging, respectively, to Clades $\mathrm{A}$ and $n \mathrm{~A}$ and $\mathrm{B}$ and $n \mathrm{~B}$ (Figs. 1C \& 3). This assumption could help in understanding whether different morphs of Lysidice ninetta are present in the Mediterranean and, consequently, how many are stable and which is the oldest.
The Atlantic origin and a previous study on the phylogeographic distribution of Lysidice ninetta (Iannotta et al. 2007) have already suggested a west to east expansion of the species in the Mediterranean basin after the Messinian evaporation and salinity crisis ( 5.5 million years ago). The genetic similarity among the sequences of the dark individuals analysed in the present work and those of L. ninetta reported in the literature (GenBank Accession Number AY838834) and collected in the Atlantic Ocean near the type locality (Struck et al. 2006) support the hypothesis of the introduction of the target species through the Strait of Gibraltar.

The genetic homogeneity characterising the western populations, the continuous decrease of the dark haplotype in central-eastern populations of the Mediterranean basin and the opposite trend observed for the light haplotype (heterogeneous sequences for individuals from eastern to central stations and absence in the western part of the Mediterranean), could lead to the hypothesis that the Atlantic Lysidice ninetta is the dark morph/haplotype. A process of vicariance for the dark haplotype, followed by the origin and dispersion of the light morph/haplotype (Fig. 5) is suggested here. This hypothesis was not supported by significant values when the Tajima's and Fu's statistical tests and the mismatched distribution analyses were computed for the 2 groups (A \& B; Figs. 1 \& 4a,b, Table 3). The results were probably related to paucity of samples, so, to overcome this bias, all individuals from Ischia (Cava dell'Isola), separated into $n \mathrm{~A}$ and $n \mathrm{~B}$ haplotypes, were added, respectively, to Groups A and B and analysed as dark and light populations (Table 3). Tajima's (1989) $D$-values were negative for both dark and light morphs, but significant only for the light $(p=0.01)$, whereas Fu's (1997) $F_{\mathrm{s}}$-test resulted in positive and
Fig. 5. Lysidice ninetta. Phylogeographic hypothesis of spatially separate species under vicariance $(-)$ and dispersal (....) based on the 16S Locus 290 variability among populations from the Mediterranean Sea. D: dark morph; L: light morph

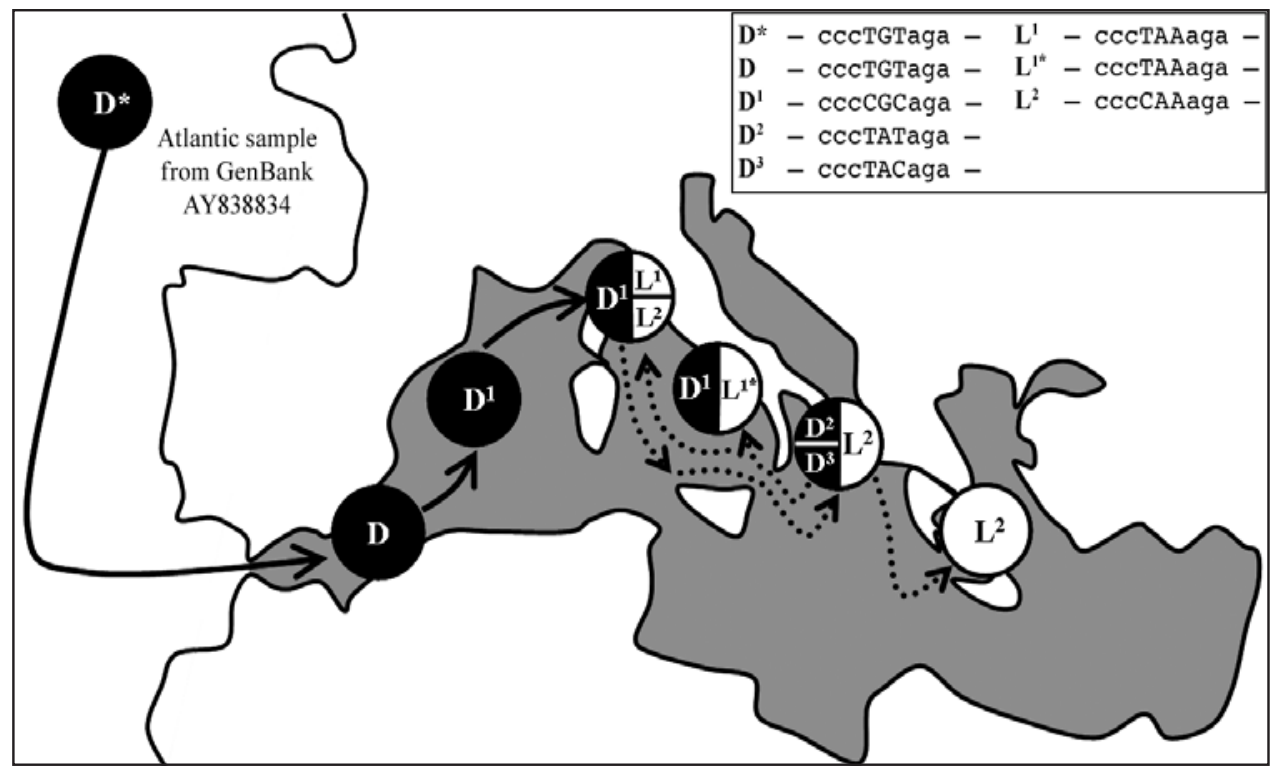




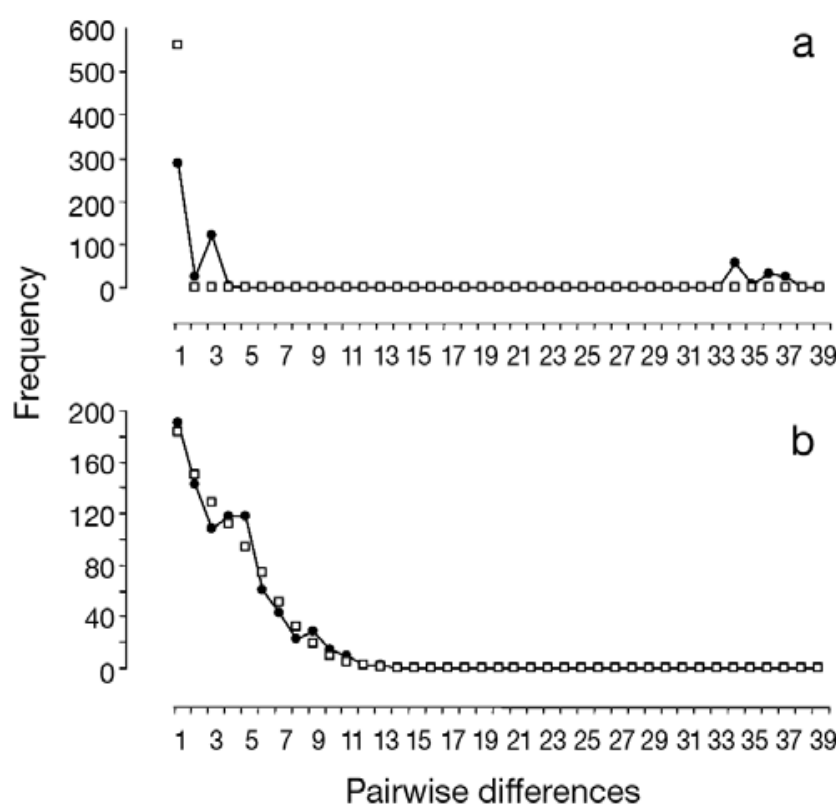

Fig. 6. Lysidice ninetta. Mismatch distribution based on 73 sequences of a $481 \mathrm{bp}$ fragment of the mitochondrial gene $16 \mathrm{~S}$ rRNA. The line shows the frequency distribution of the observed pairwise differences. White squares show the frequency distribution of the expected pairwise differences under the sudden expansion model. (a) L. ninetta 'dark' populations from the Mediterranean Sea plus Cava dell'Isola individuals and (b) L. ninetta 'light' populations from the Mediterranean Sea plus Cava dell'Isola individuals

non-significant values for the dark morph and negative and highly significant values $(\mathrm{p}<0.001)$ for the light morph (Table 3$)$. The demographic history of $L$. ninetta mirrored a situation in which the dark morph continued to show a population statistically close to the equilibrium (Fig. 6a), whereas the mismatch distribution of the light morph (Fig. 6b) was compatible with that of a population affected by sudden expansion. This hypothesis is supported by the low and statistically non-significant values of the sum of square deviations (SSD) and raggedness statistic (rg) (Harpending 1994). All of the above considerations originate, however, from the assumption that the dark form represents the 'true' L. ninetta originally described for the English Channel.

The results obtained by the study of the 6 populations in the Mediterranean, even if based on only a few individuals at each site, gave us an idea of the distribution of the 2 main haplotypes of the Lysidice ninetta complex and allowed us to concentrate our sampling effort on a single site (Ischia, Cava dell'Isola) where both occurred. Moreover, the comparable data obtained by genetic and preliminary morphological analyses of the Ischia population supported the hypothesis that these haplotypes are actually different species.
One of the main characters that led us to first separate the 2 morphs was the colouration of the anterior body, although the significance of such colour differences is unclear (Tarjuelo et al. 2004). Strong genetic variability associated with both colour and sexual strategy have been found in different fishes (McCartney et al. 2003). Among marine invertebrate species, studies of ascidians have pointed out discordant results. Colour polymorphism has not been considered a valid taxonomic status by some authors (Yund \& O'Neil 2000); for others, genetic differentiation can be also indicated through colour variation, e.g. in ascidians (Tarjuelo et al. 2001, 2004, Turon et al. 2003). In polychaetes, studies relating genetic structure to different patterns in the colouration of a given species are not yet available. However, a melanic morph described in the polar polynoid polychaete Harmothoe spinosa (dark form according to Stiller 1996) resulted in being a different species ( $H$. fuligineum) when comparisons with type material and several specimens were made (Barnich et al. 2006). Recent observations in the Caribbean Sea of individuals from the genus Lysidice showed various morphs with distinct colour patterns among specimens associated with dead rubble corals, as well as with the seagrass Thalassia testudinum (Gambi et al. 2003, Carrera-Parra et al. 2007 and their unpubl. data). In the Caribbean, all Lysidice species have usually been synonymised with $L$. ninetta (Fauchald 1970), although the species is not present in the area based on these recent findings (Carrera Parra et al. 2007). Among the 'new' Caribbean species, one, designated Lysidice sp. c in Carrera Parra et al. (2007) occurs with 2 morphs, with very distinct colouration patterns on the anterior body, but which are genetically equivalents (based on the COI molecular marker; M. A. Iannotta et al. unpubl. data). However, in Lysidice sp. $\mathrm{c}$, the other characters were similar among the differently coloured morphs, and the colouration patterns all showed different smoothing gradations, from very distinct patterns to an indistinct, uniform one, as well as discolouration once the specimens were fixed in formalin (L. Carrera-Parra et al. unpubl. data).

Regarding our 2 Lysidice ninetta colour morphs, their genotypic distinction leads us to hypothesise the presence of different species and, therefore, to call into question the present species definition and description.

The hypotheses that can be formulated are the following: (1) only a single new species is present in our material, the light morph/genotype, while the dark morph/genotype corresponds to the known Atlantic Lysidice ninetta; (2) both morphs/genotypes (dark and light) represent new taxa and need to be fully and properly described, since neither of them corresponds to the known $L$. ninetta type species; (3) one or both of the morphs/genotypes described here correspond to 
previously described species, but, since they have been synonymised by previous authors as L. ninetta, they still need to be re-described. In all cases, there is an urgent need for revision of the genus and of the nominal species of Lysidice from the Mediterranean Sea basin. As stated in the 'Introduction', this goal goes far beyond the scope of the present work. Various species of Lysidice have been, in fact, described from the Mediterranean. In particular, Grube (1855) described Lysidice punctata near Trieste and in other areas of the Mediterranean, while Claparède (1864) described Lysidice mahagoni from the Gulf of Naples. Both of these descriptions are very poor and both species were synonymised with L. ninetta by Fauvel (1923); from the available descriptions in the original literature, the colour pattern of both nominal species could be closer to the dark morph (or Clade B) than to the light one (Clade A), and therefore to the known and true $L$. ninetta. However, analysis of further material from our sites, as well as from other areas of the Mediterranean, is necessary to complete a full and appropriate description of our 2 morphs and to resolve their taxonomic position. A similar issue involves another species of the genus Lysidice, L. collaris, which is considered to be an introduced taxon (Ben Eliahu 1972) and the presence of which in the Mediterranean is questioned, based on its possible confusion with Lysidice margaritacea (Çinar 2005), described for the Gulf of Naples by Claparède (1868) and again synonymised with $L$. ninetta by Fauvel (1923).

Due to difficulties in species identification and naming, and because of the limited material we were able to examine from the main study area (Cava dell'Isola), we propose preliminary designations for the morphs/ genotypes (species?) we recorded in the present study as Lysidice-Clade A or L. ninetta-light-form and LysidiceClade B or L. ninetta-dark-form.

In conclusion, regarding the Lysidice ninetta specimens from Cava dell'Isola, an initial relationship between the genetic structure and colour morph of the individuals investigated has been determined. The genetic analyses showed 2 strongly separated haplotypes ( $n \mathrm{~A}$ and $n \mathrm{~B} ;$ Fig. 3 ). The first, less frequent and characterised by individuals with identical sequences (except for Locus 290; Fig. 5), was clearly separated from the second one, which showed a more heterogeneous genetic structure. The nucleotide distance was estimated ( $p=0.149$ ) with the Kimura 2-parameter model (Kimura 1980), and the mutation rate of the 16S mitochondrial region was hypothesised considering the range value between the mutation rate generally used for the entire mitochondria $(\mu=2 \%$ ) (Ballard \& Whitlock 2004) and the highest value of variability referred to the COI region ( $\mu=2.2 \%$ ) (Knowlton et al. 1993), and has already been used for the study of some polychaete species (Chevaldonné et al. 2002, Jolly et al. 2006). In relation to this assumption, the time divergence between the 2 haplotypes of $L$. ninetta dated back to 3.7 to 3.4 million years ago. These results confirmed similar previous data obtained for the same species with the mitochondrial marker (COI) (Iannotta et al. 2007) and further support the presence of different species under previous identifications as Lysidice ninetta. Detailed and appropriate descriptions of these species are needed based on collection and analysis of further material, as well as the revision of type material of the other nominal species described for the Mediterranean.

Acknowledgements. Thanks are due to the Molecular Biology Service of the Stazione Zoologica in Naples for technical support in molecular sequence analyses. Mariamichela Cigliano helped with worm collection at Cava, and Claudio Vasapollo kindly gave photographic support.

\section{LITERATURE CITED}

Arnold ML (1997) Natural hybridization and evolution. Oxford University Press, New York

Ballard JWO, Whitlock MC (2004) The incomplete natural history of mitochondria. Mol Ecol 13:729-744

Barluenga M, Stolting KN, Salzburger W, Muschick M, Meyer A (2006) Sympatric speciation in Nicaraguan crater lake cichlid fish. Nature 439:719-723

Barnich R, Fiege D, Micaletto G, Gambi MC (2006) Redescription of Harmothoe spinosa Kinberg, 1856 (Polychaeta, Polynoidae) and related species from Subantarctic and Antarctic waters, with the erection of a new genus. J Nat Hist 40:33-75

Ben-Eliahu MN (1972) Littoral Polychaeta from Cyprus. Tethys 4:85-94

Bianchi CN (2007) Biodiversity issues for the forthcoming tropical Mediterranean Sea. Hydrobiologia 580:7-21

Bleidorn C, Kruse I, Albrecht S, Bartolomaeus T (2006) Mitochondrial sequence data expose the putative cosmopolitan polychaete Scoloplos armiger (Annelida, Orbiniidae) as a species complex. BMC Evol Biol 6:47

Cantone G (1993) Censimento dei Policheti dei mari italiani: Eunicidae, Berthold, 1927. Atti Soc Toscana Sci Nat Mem Ser B 100:229-243

Carrera-Parra L, Fauchald K, Gambi MC (2007) Revision of the taxonomic status of Lysidice Savigny (Polychaeta, Eunicidae) in the Western Caribbean Sea with observations on reproductive features and habitat preference of different species. In: Smithsonian Marine Science Symposium (Abstract). Available at: www.si.edu/marinescience/ symposium/speakers/fauchald_ab.htm

Chevaldonné P, Jollivet D, Desbruyères D, Lutz RA, Vrijenhoek RC (2002) Sister-species of eastern Pacific hydrothermal vent worms (Ampharetidae, Alvinellidae, Vestimentifera) provide new mitochondrial COI clock calibration. Cah Biol Mar 43:367-370

Çinar ME (2005) Polychaetes from the coast of northern Cyprus (Eastern Mediterranean Sea), with two new records for the Mediterranean Sea. Cah Biol Mar 46:143-161

Claparède E (1864) Glanures zootomiques parmi les Annélides del Port-Vendres. Mem Soc Phys Hist Nat Genèva $17: 463-600$ 
Claparède E (1868) Les Annèlides Chétopodes du Golfe de Naples. Mem Soc Phys Hist Nat Genèva 20:365-542

Collin R (2005) Development, phylogeny, and taxonomy of Bostrycapulus (Caenogastropoda: Calyptraeidae), an ancient cryptic radiation. Zool J Linn Soc 144:75-101

Curini-Galletti M, Casu M (2003) Species composition and biogeographical relationship of the Proseriata (Platyhelminthes) of the Mediterranean Sea. Biogeographia 24: 115-130

Doyle JJ, Doyle JL (1987) A rapid DNA isolation procedure for small quantities of fresh leaf tissue. Phytochem Bull 19: $11-15$

Excoffier L, Smouse PE, Quattro JM (1992) Analysis of molecular variance inferred from metric distances among DNA haplotypes: application to human mitochondrial DNA restriction data. Genetics 131:479-491

Fauchald K (1970) Polychaetous annelids of the family Eunicidae, Lumbrineridae, Iphitimidae and Dorvilleidae from western Mexico. Allan Hancock Monogr Mar Biol 5:1-335

Fauvel P (1923) Polychètes errantes. Faune de France 5. Paul Lechevalier, Paris

$>$ Fu YX (1997) Statistical tests of neutrality of mutations against population growth and background selection. Genetics 147:915-925

Gambi MC (2000) Polychaete borers of the Posidonia oceanica (L.) Delile scales: distribution patterns and ecological role. Biol Mar Med 7:215-219

Gambi MC, Cigliano M (2006) Observations on reproductive features of three species of polychaete Eunicidae associated to Posidonia oceanica seagrass meadows of the Mediterranean Sea. Sci Mar 70(S3):301-308

Gambi MC, van Tussenbroek BI, Brearley A (2003) Mesofaunal borers in seagrasses: world-wide occurrence and a new record of boring polychaetes in the Mexican Caribbean. Aquat Bot 76:65-77

Gambi MC, Trani B, Buia MC (2005) Taxonomic diversity and distribution of polychaete and isopod borers on the sheaths of the seagrass Posidonia oceanica: analysis at regional scale along the coast off Sardinia (Italy). Ital J Zool 72: 141-151

George JD, Hartmann-Schröder G (1985) Polychaetes: British Amphinomida, Spintherida and Eunicida. Synop Br Fauna New Series 32:1-221

Giangrande A (1997) Polychaete reproductive patterns, life cycles and life histories: an overview. Oceanogr Mar Biol Annu Rev 35:323-386

> Grassle J, Grassle JF (1976) Sibling species in the marine pollution indicator Capitella (Polychaeta). Science 192:567-569

Grube AE (1855) Beschreibung neuer oder wenig bekannter Anneliden. Arch Naturg Berlin 21:81-136 Plates 3-5

Guo SW, Thompson EA (1992) Performing the exact test of Hardy-Weinberg proportion for multiple alleles. Biometrics $48: 361-372$

> Harpending HC (1994) Signature of ancient population growth in a low-resolution mitochondrial DNA mismatch distribution. Hum Biol 66:591-600

Iannotta A, Patti FP, Ambrosino M, Procaccini G, Gambi MC (2007) Phylogeography of two species of Lysidice (Polychaeta, Eunicidae) associated to the seagrass Posidonia oceanica in the Mediterranean Sea. Mar Biol 150: 1115-1126

Jolly MT, Viard F, Gentil F, Thiebaut E, Jollivet D (2006) Comparative phylogeography of two coastal polychaete tubeworms in the Northeast Atlantic supports shared history and vicariant events. Mol Ecol 15:1841-1855

Kidd DM, Ritchie MG (2006) Phylogeographic information systems: putting the geography into phylogeography. J Biogeogr 33:1851-1865
Kimura M (1980) A simple method for estimating evolutionary rate of base substitutions through comparative studies of nucleotide sequences. J Mol Evol 16:111-120

Knowlton N (1993) Sibling species in the sea. Annu Rev Ecol Syst 24:189-216

- Knowlton N (2000) Molecular genetic analyses of species boundaries in the sea. Hydrobiologia 420:73-90

Knowlton N, Weigt LA, Solòrzano LA, Mills DK, Bermingham E (1993) Divergence in proteins, mitochondrial DNA, and reproductive compatibility across the Isthmus of Panama. Science 260:1629-1632

Kruse I, Reusch TBH, Schneider MV (2003) Sibling species or poecilogony in the polychaete Scoloplos armiger. Mar Biol 142:937-947

Kumar S, Tamura K, Nei M (2004) MEGA3: integrated software for molecular evolutionary genetics analysis and sequence alignment. Brief Bioinform 5:150-163

Maddison WP, Knowles LL (2006) Inferring phylogeny despite incomplete lineage sorting. Syst Biol 55:21-30

Maddison WP, Maddison DR (2008) Mesquite: a modular system for evolutionary analysis, Ver 2.5. Available at: http:// mesquiteproject.org

Maltagliati F, Casu M, Castelli A (2004) Morphological and genetic evidence supports the existence of two species in the genus Ophelia (Annelida, Polychaeta) from the Western Mediterranean. Biol J Linn Soc 83:101-113

Martin D (1987) Anélidos poliquetos asociados a las concreciones de algas calcáreas del litoral catalán. Misc Zool 11: $61-75$

> McCartney MA, Acevedo J, Heredia C, Rico C, Quenoville B, Bermingham E, Owen Mcmillan W (2003) Genetic mosaic in a marine species flock. Mol Ecol 12:2963-2973

Murina V (1992) Phenology of pelagic larvae of Polychaeta in the adjacent of the Mytilus farm off the southern coast of Crimea. In: Bushinskaja GN (ed) Polychaeta and their ecological significance: explorations of the fauna of the seas 43(51):152-157 (in Russian with English abstract)

Murina V (1997) Pelagic larvae of Black Sea Polychaeta. Bull Mar Sci 60:427-432

Palumbi SR (1992) Marine speciation on a small planet. Trends Ecol Evol 7:114-118

Palumbi SR (1994) Genetic divergence, reproductive isolation, and marine speciation. Annu Rev Ecol Syst 25:547-572

Palumbi SR (1996) Nucleic acids. II. The polymerase chain reaction. In: Hillis DM, Moritz C, Mable BK (eds) Molecular systematics. Sinauer Associates, Sunderland, MA, p 205-247

Pechenik JA (1999) On the advantages and disadvantages of larval stages in benthic marine invertebrate life cycles. Mar Ecol Prog Ser 177:269-297

Posada D, Crandall KA (1998) Modeltest: testing the model of DNA substitution. Bioinformatics 14:817-818

Rouse GW, Plejel F (2006) Polychaetes, 2nd edn. University Press, Oxford

Schröder T, Walsh EJ (2007) Cryptic speciation in the cosmopolitan Epiphanes senta complex (Monogononta, Rotifera) with the description of three new species. Hydrobiologia 593:129-140

Sirna Terranova M, Lo Brutto S, Arculeo M, Mitton JB (2006) Population structure of Brachidontes pharaonis (P. Fisher, 1870) (Bivalvia, Mytilidae) in the Mediterranean Sea, and evolution of a novel mtDNA polymorphism. Mar Biol 150: 89-101

Stiller M (1996) Verbreitung und Lebensweise der Aphroditiden und Polynoiden (Polychaeta) im östlichen Weddellmeer und im Lazarevmeer (Antarktis). Ber Polarforsch 185: $1-200$

Struck TH, Purschke G, Halanich KM (2006) Phylogeny of 
Eunicida (Annelida) and exploring data congruence using a partition addition bootstrap alteration (PABA) approach. Syst Biol 55:1-20

Swofford DL (2003) PAUP*: Phylogenetic analysis using parsimony ( ${ }^{*}$ and other methods), Ver 4.0b 10. Sinauer Associates, Sunderland, MA

Tajima F (1989) Statistical methods to test for nucleotide mutation hypothesis by DNA polymorphism. Genetics 123: 585-595

Tarjuelo I, Posada D, Crandall KA, Pascual M, Turon X (2001) Cryptic species of Clavelina (Ascidiacea) in two different habitats: harbours and rocky littoral zones in the Northwestern Mediterranean. Mar Biol 139:455-462

Tarjuelo I, Posada D, Crandall KA, Pascual M, Turon X (2004) Phylogeography and speciation of colour morphs in the colonial ascidian Pseudodistoma crucigaster. Mol Ecol 13: 3125-3136

Turon X, Tarjuelo I, Duran S, Pascual M (2003) Characterizing

Editorial responsibility: Riccardo Cattaneo-Vietti,

Genova, Italy invasion processes with genetic data: an Atlantic clade of Clavelina lepadiformis (Ascidiacea) introduced into Mediterranean harbours. Hydrobiologia 503:29-35

Westheide W, Schmidt H (2003) Cosmopolitan versus cryptic meiofaunal polychaete species: an approach to a molecular taxonomy. Helgol Mar Res 57:1-6

Wilson WH (1991) Sexual reproductive modes in polychaetes: classification and diversity. Bull Mar Sci 48:500-516

Yund PO, O'Neil PG (2000) Microgeographic genetic differentiation in a colonial ascidian (Botryllus schlosseri) population. Mar Biol 137:583-588

Zanol J, Fauchald C, Paiva PC (2007a) A phylogenetic analysis of the genus Eunice (Eunicidae, Polychaeta, Annelida). Zool J Linn Soc 150:413-434

Zanol J, Halanych KM, Fauchald K (2007b) Phylogeny of Eunicidae (Annelida) based on 16S, COI and 18S sequences. In: Abstracts from the 9th Polychaete Conference. Portland, ME, p 88

Submitted: September 18, 2008; Accepted: April 10, 2009

Proofs received from author(s): July 17, 2009 